\title{
KEARIFAN LOKAL MASYARAKAT DALAM MEMANFAATKAN LAHANG KERING DI DESA BUMI PAJO KECAMATAN DONGGO KABUPATEN BIMA
}

\author{
${ }^{1}$ Mas'ad, ${ }^{2}$ Sri Yuliani \\ ${ }^{1,2}$ Dosen Program Studi Pendidikan Geografi, Universitas Muhammadiyah Mataram \\ Email : siti.masad@yahoo.com
}

\begin{abstract}
ABSTRAK
Seiring dengan pergeseran paradigma pengembangan pertanian intensif di lahan basah sebagai penopang utama kebutuhan pangan nasional, maka pengembangan pertanian di lahan kering merupakan alternatif yang sangat penting. Harapan besar dari pemanfaatkan lahan kering adalah kesejahteraan hidup masyarakat petani sekaligus mengentaskan kemiskinan. Kearifan lokal menjadi suatu hal yang menarik untuk dikaji dan mempunyai peranan penting dalam dinamika lingkungan. Perlu disadari bahwa kearifan lokal mampu menjaga kelestarian dalam bentuk suatu panutan ataupun kebiasaan yang disakralkan dan dalam bentuk penanda yang harus dipatuhi oleh masyarakat yang sifatnya turun temurun. Kearifan lokal dalam pemanfaatan lahan kering di desa Bumi Pajo merupakan warisan budaya dari nenek moyang yang mampu menjaga kelestarian lingkungan dan meningkatkan produktivitas lahan kering yang berdampak pada meningkatnya pendapatan petani. Tujuan Penelitian untuk: (1) Mendeskripsikan bentuk kearifan lokal masyarakat dalam memanfaatkan lahan kering di desa BUmi Pajo Kecamatan Donggo kabupaten Buma. (2). Medeskripsikan peran kearifan lokal masyarakat dalam memanfaatkan lahan kering di desa Bumi Pajo kecamatan Donggo kabupaten Bima. Penelitian ini menggunakan metode kualitatif, tehnik penentuan informan dengan menggunakan purposive sampling dengan informan penelitian adalah petani lahan kering dan informan biasanya masyarakat umum. Tehnik pengumpuln data menggunakan tehnik observasi, wawancara dan dokumentasi. Hasil penelitian ini menunjukkan bahwa bentuk kearifan lokal masyarakat dalam memanfaatkan lahan kering di desa Bumi Pajo kecamatan Donggo kabupatn Bima adalah Toho ra dore, Yasinan dan Wi'i kamaya, yang merupakan warisan dari nenek moyang mereka sementara Peran kearifan lokal mengarahkan masyarakat untuk bekerja dengan baik dan benar atau dengan kata lain mengarahkan masyarakat cara bertani yang arif dan bijaksana, teutama dalam hal pengelolaan atau pemanfaatan lahan kering sehingga terjaga keseimbangan dan kelestarian lingkungan dan meningkatnya kesuburan tanah. Dengan demikian dalam hal bertani terutama bertani dilahan kering masyarakat bisa mendapatkan hasil sesuai dengan yang diinginkannya.
\end{abstract}

Kata kunci: Kearifan Lokal dan Lahan Kering

\section{PENDAHULUAN}

Seiring dengan pergeseran paradigma pengembangan pertanian intensif di lahan basah sebagai penopang utama kebutuhan pangan nasional, maka pengembangan pertanian di lahan kering merupakan alternatif yang sangat penting. Nusa Tenggara Barat (NTB) wilayah dengan berbagai jenis penggunaan. Data BPS NTB (2002), menunjukkan bahwa luas lahan kering yang potensial untuk tanaman pangan adalah seluas 211.635 ha, yang terdiri atas ladang/huma 40.636 ha dan tegalan/kebun seluas 171.000 ha. Sebagian besar kondisi lahan kering di NTB di cirikan dengan iklim yang kering yaitu tipe iklim D3 (3-4 bulan basah dan 4-6 bulan kering), tipe iklim D4 (3-4 bulan basah dan $>6$ bulan kering), tipe E3 ( $<3$ bulan basah, 4-6 bulan kering) dan tipe iklim E4 (<3 bulan basah dan > 6 bulan kering) (Oldeman, et al, 1980). Distribusi dan intensitas curah hujan tidak merata dan tidak menentu (eratik) sehingga seringkali terjadi gagal panen akibat cekaman air. Selain itu sifat tanah yang porus dimana tanah tidak mampu memegang air dalam jangka waktu yang lama. Dengan kondisi tersebut, maka usahatani di lahan kering sangat tergantung pada curah hujan. Salah satu komoditas yang cocok dan banyak diusahakan petani di lahan kering pada musim hujan adalah kedelei, kacang panjang, palawija, padi dan jagung. Kemudian pemanfaatan potensi lahan kering yang ada guna meningkatkan produktivitas beberapa jenis tanaman tersebut dapat ditempuh dengan melakukan identifikasi berbagai permasalahan baik bio-fisik maupun sosial ekonomi dan budaya melalui pendekatan partisipatif, serta mengatasi permasalahan aktual dengan menerapkan pendekatan Pengelolaan Tanaman Terpadu (PTT) yang spesifik lokasi. Komponen teknologi produksi yang diterapkan disesuaikan dengan kondisi biofisik, sosial ekonomi dan 
budaya setempat. Dengan penerapan teknologi ini, diharapkan dapat meningkatkan produktivitas dan pendapatan petani.

Lahan atau tanah merupakan sumber daya alam fisik yang mempunyai peranan penting dalam segala kehidupan manusia, karena lahan atau tanah diperlukan manusia untuk tempat tinggal dan hidup, melakukan kegiatan pertanian, peternakan, perikanan, kehutanan, pertambangan dan sebagainya. Karena pentingnya peranan lahan atau tanah dalam kehidupan manusia, maka ketersediaannya juga jadi terbatas. Keadaan ini menyebabkan penggunaan tanah yang rangkap (tumpang tindih), misalnya tanah sawah yang digunakan untuk perkebunan tebu, kolam ikan atau penggembalaan ternak atau tanah hutan yang digunakan untuk perladangan atau pertanian lahan kering. Berdasarakan uraiana tersebut maka perlu dilakukan kajian yang berkaitan dengan bagaimana cara memanfaatkan lahan kering yang arif agar dapat mendukung kelestarian dan keseimbangan lahan agar dapat meningkatkan produktivitas dan pendapatan petani.

Rumusan Masalah dalam penelitian ini : "(1) Bagaimana Bentuk kearifan lokal masyarakat dalam pemanfaatan lahan kering di desa Bumi Pajo kecamatan Donggo kabupaten Bima. (2). Bagaimana Peran kearifan lokal masyarakat dalam memanfaatkan lahan kering di desa Bumi Pajo kecamata Donggo Kabupaten Bima? Tujuan penelitian untuk: (1) Mendeskripsikan bentuk kearifan lokal masyarakat dalam pemanfaatan lahan kering di desa BUmi Pajo kecamatan Donggo kabupaten Bima. (2) Mendeskripsikan Peran kearifan lokal masyarakat dalam pemanfaatan lahan kering di Desa Bumi Pajo Kecamatan Donggo Kabupaten Bima.

\section{TINJAUAN PUSTAKA}

\section{A. Kearifan Lokal}

Kearifan lokal (local wisdom) dalam kamus terdiri dari dua kata: kearifan (wisdom) dan lokal (loca). Dalam Kamus Inggris Indonesia, local berarti setempat, sedangkan wisdom (kearifan) sama dengan kebijaksanaan. Secara umum maka local wisdom (kearifan setempat) dapat dipahami sebagai gagasan-gagasan setempat (local) yang bersifat bijaksana, penuh kearifan, bernilai baik, yang tertanam dan diikuti oleh anggota masyarakatnya (Erniwati, 2010). Kearifan lokal merupakan produk budaya masa lalu yang patut secara terus-menerus dijadikan pegangan hidup. Meskipun bernilai lokal tetapi nilai yang terkandung didalamnya dianggap sangat universal (Iwan, 2012). Ahli lain yaitu Nyamai (2010), menyatakan kearifan lokal adalah sumber pengetahuan yang diselenggarakan dinamis, berkembang dan diteruskan oleh populasi tertentu yang terintegrasi dengan pemahaman mereka terhadap alam dan budaya sekitarnya. Kearifan lokal adalah dasar untuk pengambilan kebijakkan pada level lokal dibidang kesehatan, pertanian, pendidikan, pengelolaan sumber daya alam dan kegiatan masyarakat pedesaan. Dalam kearifan lokal, terkandung pula kearifan budaya lokal.

\section{B. Bentuk-bentuk Kearifan Lokal}

Bentuk kearifan lokal

dapat dikategorikan ke dalam dua aspek, yaitu kearifan lokal yang berwujud nyata (tangible) dan yang tidak berwujud (intangible).

a. Kearifan Lokal yang Berwujud Nyata (Tangible).

1) Tekstual, Beberapa jenis kearifan lokal seperti sistem nilai, tata cara, ketentuan khusus yang dituangkan ke dalam bentuk catatan tertulis seperti yang ditemui dalam kitab tradisional primbon, kalender dan prasi (budaya tulis di atas lembaran daun lontar).

2) Bangunan/Arsitektural

3) Benda Cagar Budaya/Tradisional (Karya Seni), misalnya keris, batik dan lain-lain.

b. Kearifan Lokal yang Tidak Berwujud (Intangible)

Selain bentuk kearifan lokal yang berwujud, ada juga bentuk kearifan lokal yang tidak berwujud seperti petuah yang disampaikan secara verbal dan turun temurun yang dapat berupa nyanyian dan kidung yang mengandung nilai-nilai ajaran tradisional. Melalui petuah atau bentuk kearifan lokal yang tidak berwujud lainnya, nilai sosial disampaikan secara oral/verbal dari generasi ke generasi. Misalnya kearifan lokal yang mengandung etika terhadap lingkungan.

\section{Masyarakat}

Masyarakat (society) adalah sekelompok orang yang membentuk sebuah sistem semi tertutup atau sebaliknya, dimana kebanyakan interaksi adalah antara individu-individu yang terdapat dalam kelompok tersebut. Pada umumnya sebutan masyarakat dipakai untuk mengacu sekelompok individu yang hidup bersama dalam satu komunitas yang teratur (Todaro, 2006). Ahli lain yaitu An-Nabhani 
(2011), menjabarkan tentang definisi masyarakat, "sekelompok manusia bisa disebut sebagai suatu masyarakat apabila mempunyai pemikiran, perasaan, serta sistem atau aturan yang sama". Dengan kesamaan itu, manusia lalu berhubungan saling berinteraksi antara sesama mereka berdasarkan kepentingan bersama.

\section{Lahan Kering}

Lahan kering adalah hamparan lahan yang di dayagunakan tanpa penggenangan air, baik secara permanen maupun musiman dengan sumber air berupa air hujan atau air irigasi (Suwardji, 2003:3). Satari (dalam Guritno, 2011: 20) berpendapat bahwa yang dimaksud dengan lahan kering adalah lahan yang dalam keadaan alamiah, lapisan atas dan bawah tubuh tanah (top soil dan sub soil) sepanjang tahun tidak jenuh air dan tidak tergenang, serta kelembaban tanah sepanjang tahun atau hampir sepanjang tahun berada di bawah kapasitas lapang.
Sedangkan Muliady (dalam Guritno, 2011: 20) menyatakan bahwa lahan kering adalah tanah yang hampir sepanjang tahun tidak tergenang secara permanen.

\section{E. Kerangka Teori}

Kerangka teori adalah landasan berpikir yang bersumber dari suatu teori yang sering diperlukan sebagai tuntunan untuk memecahkan berbagai permasalahan dalam sebuah penelitian. Begitu pula, kerangka teori berfungsi sebagai kerangka acuan yang mengarahkan suatu peneliti. Kerangka teori merupakan perangkat konsep definisi, dan proposisi yang menyajikan gejala secara sistematik, merinci hubungan variabel-variabel untuk meramalkan dan menerangkan gejala tersebut. Teori berfungsi sebagai perspektif atau pangkal tolak dan sudut pandang untuk memahami alam pikiran subyek, menafsirkan dan memaknai setiap gejala dalam rangka membangun konsep.

\section{Gambar 1: Kerangka Teori Kearifan Lokal Masyarakat Dalam Pemanfaatan Lahan Kering}

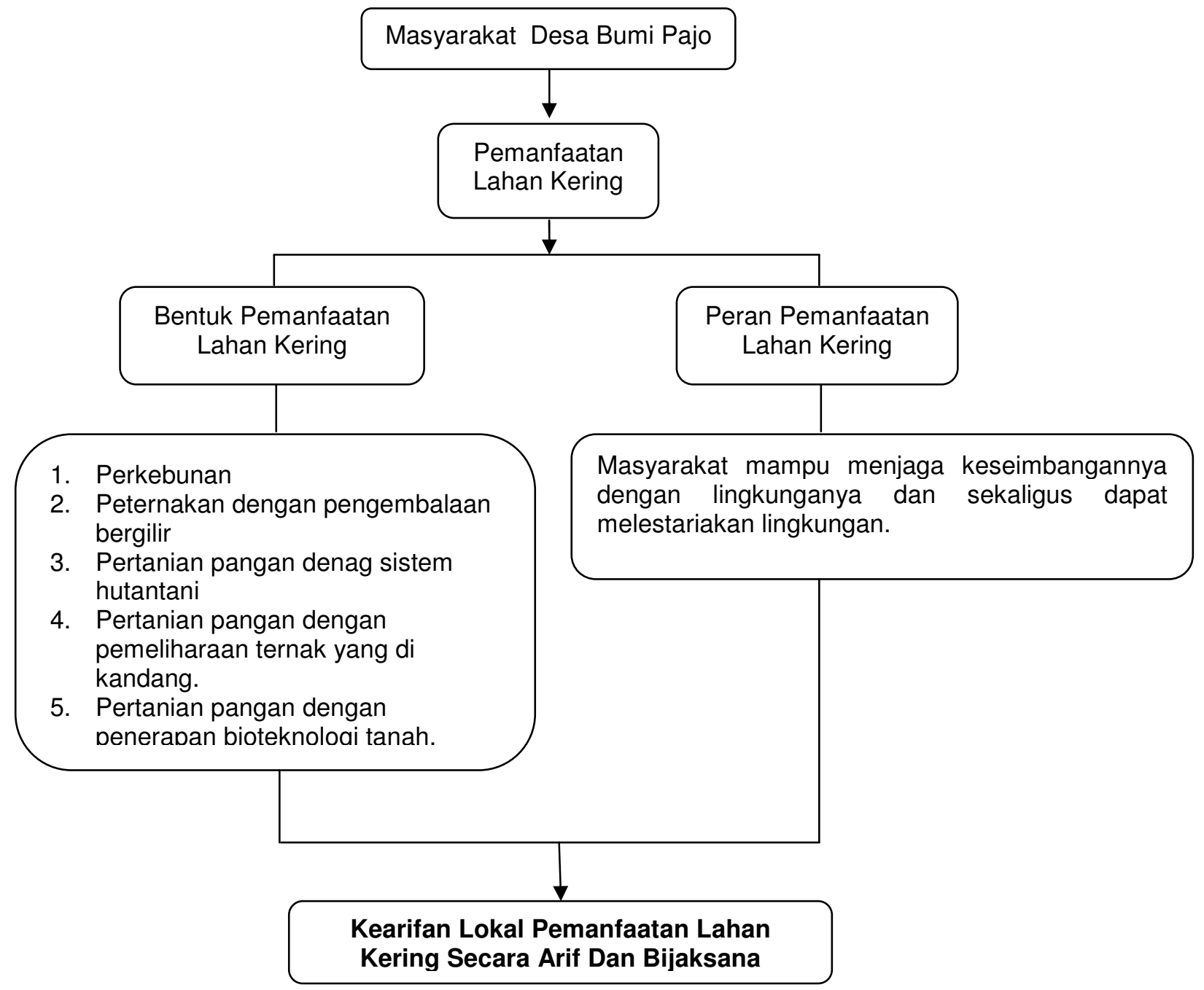




\section{METODE PENELITIAN}

Penelitian ini mengunakan metode penelitian kualitatif. Metode penelitian kualitatif sering disebut metode penelitian naturalistik karena penelitiannya dilakukan pada kondisi yang alamiah (natural setting); disebut juga sebagai kualitatif, karena data yang terkumpul dan analisisnya lebih bersifat kualitatif. Tehnik pengumpulan data melalui observasi, wawancara dengan informan penelitia dan pencatatan dokumentasi. Sumber data meliputi sumber data primer yang diperoleh melalui observasi dan wawancar sedangkan sumber data sekunder diperoleh melalui pencatatan dokumentasi. Tehnik penenentuan informan penelitian menggunakan purposive sampling dengan informen kunci adalah petani lahan kering sedangkan informan biasa adalah masyarakat umum. Untuk ketelitian maka peneliti sebagai instrumen utama terlibat langsung dalam pengumpulan data atau informasi di lapangan. Tehnik analisis data yang digunakan adalah tehnik analisis data kualitatif.

\section{HASIL DAN PEMBAHASAN}

\section{A. Deskripsi Lokasi Penelitian}

Desa Bumi Pajo Merupakan salah satu desa yang ada di kecamatan Donggo kabupataen Bima dengan luas wilayah 35.000 $\mathrm{Ha}$, dan topografi atau bentuk lahannya adalah sebagian besar berbentuk bukit dan gunung, datar sampai berombak. Sedangkan tinggi tempat dari permukaan laut $1.012 \mathrm{~m}$ diatas permukaan laut. Potensi irigasi yang dimiliki adalah berupa sungai dan bendungan. Desa Bumi Pajo beriklim tropis dengan musim hujan yang digolongkan pendek yaitu antara bulan nopember sampai bulan maret.

\section{Gambar 2. Peta Lokasi Penelitian}

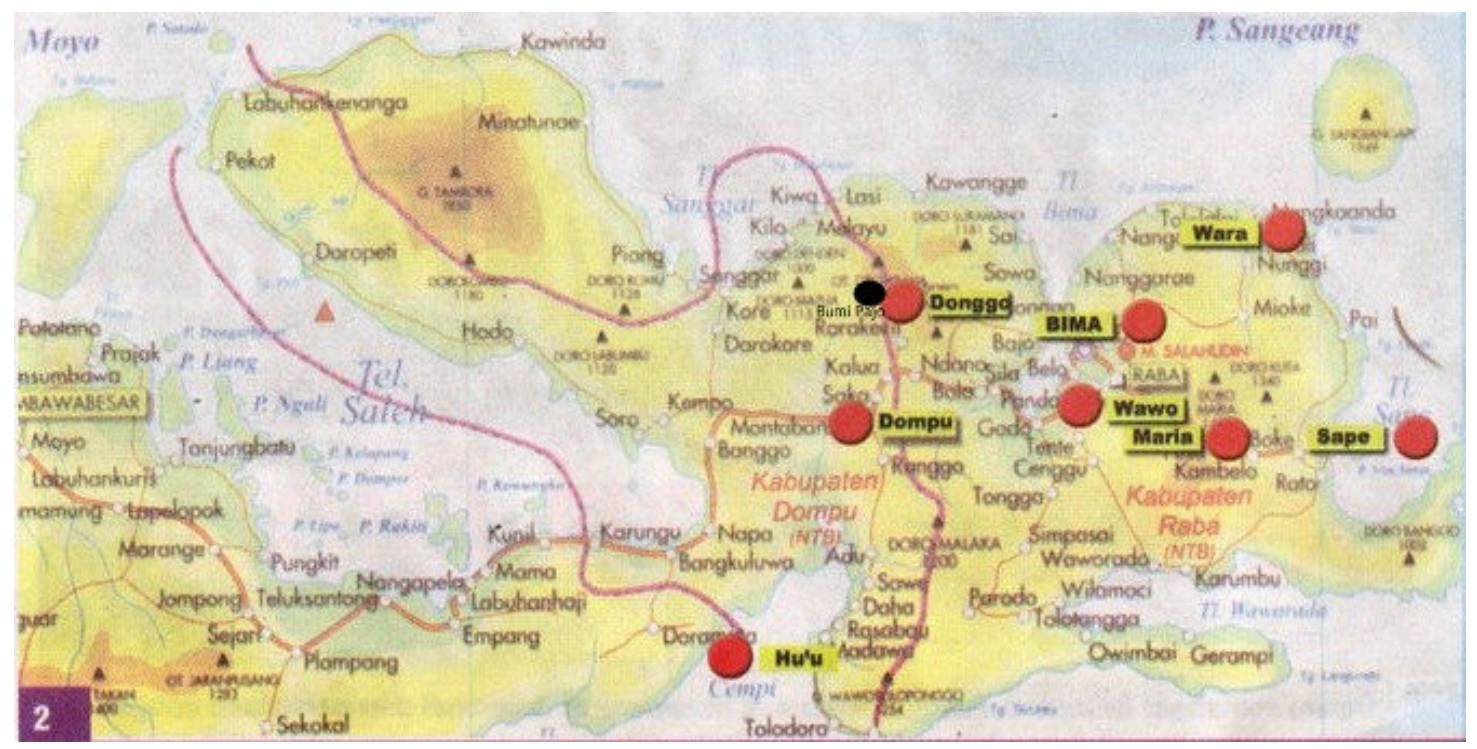

Desa Bumi Pajo terdiri dari empat dusun. Masing-masing dusun terdiri dari seorang Kepala Dusun (Kadus). Batas-batas wilayah desa Bumi Pajo sebagai beriktut:
a. Sebelah Timur berbatasan dengan Desa Mbawa
b. Sebelah barat berbatasan dengan Kabupaten Dompu
c. Sebelah utara berbatasan dengan hutan lindung/ pegunungan

d. Sebelah selatan berbatasan dengan Desa Rora dan Desa Palama

Sedangkan orbitrasi Desa Bumi Pajo adalah sebagai berikut:
a. Jarak ke kota kecamatan $50 \mathrm{~km}$
b. Jarak ke kota kabupaten $54 \mathrm{~km}$
c. Waktu tempuh ke kota kecamatan 30 menit
d. Waktu tempuh ke kota kabupaten 35 menit 


\section{B. Penduduk}

Berdasarkan data statistik desa dari hasil register penduduk bulan November, jumlah penduduk Desa Bumi Pajo 2013-2014 adalah 2.163 jiwa. Adapun perinciannya, 1.068 laki-laki dan 1.095 perempuan dengan jumlah kepala keluarga sebanyak 478 kepala keluarga. Tingkat pendidikan masyarakat Desa Bumi Pajo cukup bervariasi. Ada yang berpendidikan sekolah dasar (SD), Sekolah Lanjut Tingkat Pertama (SLTP), Sekolah Menengah Atas (SMA), bahkan sampai pada perguruan tinggi. Namun mayoritas masyarakat Desa Bumi Pajo berpendidikan SD.

\section{Mata Pencaharian Penduduk}

Keadaan Penduduk Menurut Mata Pencaharian, berdasarkan data yang diperoleh dari kantor Desa bumi pajo dan hasil observasi langsung peneliti bahwa sumber mata pencaharian masyarakat Desa Bumi Pajo adalah bertani, Pegawai Negeri Sipil (PNS), POLRI, TNI, pengusaha/pedagang, peternak dan nelayan. Tapi mayoritar mata pencaharian penduduk Bumi Pajo disektor pertanian sebesar $90 \%$. Hal ini didukung oleh kondisi wilayah desa bumi pajo yang merupakan daerah persawahan dan didukung dengan banyaknya jumlah masyarakat yang memiliki tanah sendiri, sehingga kebanyakan dari masyarakat desa bumi pajo bermata pencaharian sebagai petani.

\section{Agama yang dianut Penduduk}

Penduduk/masyarakat desa Bumi Pajo mayoritas beragama islam sehingga dalam kehidupan bermasyarakat sehari-hari diwarnai oleh aturan-aturan islam, keadaan tersebut juga diimbangi dengan tersedianya sarana peribatan berupa Masjid.

\section{E. Hasil Observasi dan Wawancara}

Berdasarkan hasil wawancara dengan salah satu informan/petani tentang kebiasaan masyarakat melakukan ritual-ritualnya adalah sebagai berikut antara lain .

1. Salah satunya adalah berdoa meminta perlindungan kepada Allah SWT. sebagai tempat meminta agar bisa sukses dalam melakukan usahanya dan dapat mencapai hasil yang di inginkan. maksudnya adalah ketika kita menginginkan sesuatu maka Allah memberikan jalan yang terbaik untuk usahanya.

2. Tentang ritual kematian, kematian dalam adat masyarakat Desa Bumi Pajo sekarang masih dilaksanakan seperti, apabila ada kematian dalam sebuah keluarga, maka semua kain-kain yang menyelimuti mayat tadi disimpan pada suatu tempat. Kain-kain ini disebut pula "kani ra lombo" adalah sisa baju yang dipakai oleh almarhum/almarhuma, biasanya disimpan di atas tempat tidur untuk selama empat puluh hari. Setelah selesai upacara penguburan selesai dilaksanakan, mulai malam pertama sampai malam ketiga diadakan "tahali" atau (tahlil).

3. Ketika kehamilan perempuan ini mencapai 7 bulan maka di adalakanlah upacara yang sering disebut oleh mereka adalah "kiri loko" yang artinya "memperbaiki bentuk perut" cara yang mereka lakukan terhadap ibu hamil ini adalah, memakaikan kain putih tampa ada alasnya di tubuh ibu hamil tadi. mereka melakukan ritual "kiri loko"ini agar mereka bisa tau anak pempuan atau lakilaki yang akan keluar nanti selain itu agar mendidik si bayi supaya kelak dia tidak akan menjadi anak yang bandel dan terhindar dari perbuatan tercela serta tunduk dan patuh terhadap orang tua keluarga dan sahabatnya dan agar bentuk fisiknya sempurna, dan setelah bayi itu lahir maka ari-ari harus di kuburkan di dalam lingkungan rumahnya, supaya bayi itu tidak rewel, bandel dan selalu sabar serta patuh terhadap ibu/bapaknya (Wawancara Tgl 0605-2015 dengan bapak Suparman 41 thn)

Hasil wawancara yang berkaitan dengan penyuluhan atau bantuan dari pemerintah terkait mengenai kearifan lokal masyarakat dalam pemanfaatan lahan kering diperoleh informasi sebagai berikut:

Saya selama menjadi petani belum menerima bantuan penyeluhan-penyuluhan pertanian untuk mendukung kearifan lokal, saya juga tidak mengerti peranya dinas pertanian. Kita justru kalau ada hama pada tanaman, kita juga tahu cara mengusir hama, jadi nggak mesti ada penyuluhan dari dinas pertanian karena kearifan lokal ini memang sudah dilaksanakan secara turun temurun oleh masyarakat petani yang ada di Desa Bumi Pajo, kearifan lokal ini merupakan tradisi nenek moyang kita pada 
jaman dahulu sampai sekarang masyarakat di Desa Bumi Pajo ini masih mempercayai tentang hal-hal tersebut (Wawancara Tgl. 08-05-2015 dengan bapak Abdul Wani 38 thn).

Hasil wawancara yang berkaitan dengan proses awal keberadaan kearifan lokal masyarakat dalam pemanfaatan lahan kering di desa Bumi Pajo kecamatan Donggo Kabupaten Bima di dukung oleh mudahnya dalam mengelola lahan garapan karena lahannya subur walaupun daerah ini merupakan lahan kering sehingga petani tidak terlalu sulit dalam mencari pola-pola penanaman yang tepat dan juga dalam pengelolaannya tidak membutuhkan biaya yang banyak, selain itu persepsi masyarakat desa Bumi Pajo keberdaan kearifan lokal masyarakat dalam pemanfaatan lahan kering masyarakat bisa mendapatkan hasil sesuai dengan yang di inginkannya.

Hasil wawancara dengan informan juga diperoleh informasi yang berkaitan dengan obyek yang diteliti yaitu bentuk-bentuk kearifan lokal masyarakat sebagai berikut:

a. Tohora dore

Istilah"toho ra dore" merupakan wujud kepercayaan masyarakat terhadap arwah leluhur, masyarakat pada saat tertentu mempunyai tujuan serta keiginan disaat mereka melakukan "toho ra dore" ini, dimana ketika mereka mengalami gagal panen atau terkena musibah, maka jalan pertama yang dilakukan oleh mereka adalah melakukan "toho ra dore" bagi mereka "toho ra dore" adalah wujud permintaan maaf mereka terhadap arwah nenek moyang dan gagal panen yang dianggap salah satu bentuk murka dari nenek moyang segera berakhir.

b. berdoa/ Yasinan

Masyarakat Desa Bumi Pajo satu hari sebelum memulai kegiatan pemanenan di lokasi pertaniannya di rumahnya masyarakat melakukan yasinan atau berdoa meminta perlindungan kepada Allah SWT, dengan tujuannya agar tanamannya yang di panen selamat dan menghasilkan rezeki yang memuaskan seperti yang diinginkan oleh petani tersebut.

c. Menyimpan Kemaya

Masyarakat Desa Bumi Pajo selesai melakukan Yasinan mereka pergi ke ladang/sawahnya dengan membawa kemaya dan arang, lalu membakar kemaya tersebut sebagai pertanda tanaman tersebut akan di panen. Dengan demikian semua mahluk yang ada disitu tidak kaget ketika tanaman di panen (Wawancara tgl 07-05-2015 dengan bapak Tasrif dan Hamdan).

Dari paparan di atas dapat disimpulkan bahwa dengan adanya bentuk kearifan lokal tersebut masyarakat merasakan apa yang diinginkannya dapat terwujud misalnya mereka merasa terlindung dari segala bahaya, meningkatnya hasil pertanian masyarakat dan terjaganya keseimbangan serta kelestarian lingkungan.

Selain bentuk-bentuk kearifan lokal tersebut ada juga kebiasaan lain yang dilakukan oleh petani dalam pemanfaatan lahan kering seperti hasil wawancara dengan informan berikut :

a. Membersihkan lahan, kebiasaan masyarakat desa Bumi Pajo selesai mereka membersihkan lahan tersebut mereka tunggu sampai kering kalau sudah kering terus di bakar, tujuannya dengan membakar sisa tanaman tersebut maka hama tanaman yang berembunyi di sekitar lokasi tersebut bisa terusir selain itu masyarakat di desa tersebut paham dengan membakar sisa tanaman dapat menambah bahan organik tanah sehigga menambah kesuburan tanah.

b. Mencampur benih dengan obat, kebiasaan masyarakat desa Bumi Pajo ketika mau tanam, masyarakat mencampur benih yang mau ditanam tersebut dengan obat agar tidak dimakan oleh semut di dalam tanah (Wawancara tgl, 09-05-2015 dengan Bpk Rusdi dan Masjidin).

Dari paparan di atas dapat disimpulkan bahwa dengan adanya kearifan lokal ini jelas masyarakat mengetahui kebiasaan dalam pemanfaatan lahan kering. Kebiasaan masyarakat dalam pemanfaatan lahan kering, masyarakat selalu senantiasa berusaha mendapatkan yang terbaik sehingga dapat memperoleh hasil yang maksimal.

Hasil wawancara dengan informan penelitian yang berkaitan dengan peran kearifan lokal dalam memanfaatkan lahan kering di desa Bumi Pajo diperoleh data-data sebagai berikut:

Kearifan lokal bagi mayarakat desa Bumi Pajo berperan mengarahkan masyarakat untuk bekerja dengan baik dan benar atau dengan kata lain mengarahkan masyarakat cara bertani yang arif dan bijaksana, teutama dalam hal pengelolaan lahan kering sehingga terjaga keseimbangan lingkungan 
(Wawancara tgl 07-05-2015 dengan bapak Tasrif dan Hamdan).

Masyarakat di desa Bumi Pajo mampu melestarikan kearifan lokal yang di milikinya yang menjadi warisan budaya nenek moyang. Karena dengan demikian dalam hal bertani terutama bertani dilahan kering masyarakat mendapatkan hasil sesuai dengan yang diinginkannya (Wawancara tgl. 07-05-2015 dengan bpk Tasrif dan Hamdan).

Kearifan lokal dalam pemanfaatan lahan kering di desa Bumi Pajo merupakan warisan dari nenek moyang yang mampu menjaga kelestarian lingkungan dalam bentuk suatu panutan ataupun kebiasaan yang disakralkan dan dalam bentuk penanda yang harus dipatuhi oleh masyarakat yang sifatnya turun temurun, kearifan memberikan dampak positif bagi masyarakat, dalam meningkatkan produktivitas lahan kering yang berdampak pada meningkatnya pendapatan petani.

Wawancara yang berkaitan dengan cara melestarikan kearifan lokal, informan memberikan pernyataan berikut:

Masyarakat di Desa Bumi Pajo dalam melestarikan kearifan lokal/tradisi jaman dahulu seperti: tohora dore /wi,i ra dore, yasinan, wi,i kamaya atau yang disebut dengan kearifan lokal itu sendiri dengan menjadikannya sebagai warisan budaya yang harus tetap dilestarikan dan bahkan diharapkan kedepannya bisa dikembangkan lagi oleh anak cucu mereka (Wawancara tanggal 09-05-2015 dengan bapak Rusdi dan Masjidin)

\section{F. PEMBAHASAN}

\section{Bentuk-Bentuk Kearifan Lokal Masyarakat dalam Memanfaatkan Lahan Kering di desa Bumi Pajo Kecamatan Donggo Kabupaten Bima}

Kearifan lokal merupakan produk budaya masa lalu yang patut secara terus-menerus dijadikan pegangan hidup. Meskipun bernilai lokal tetapi nilai yang terkandung didalamnya dianggap sangat universal. Kearifan lokal merupakan suatu hal yang menarik untuk dikaji dan mempunyai peranan penting dalam dinamika lingkungan, bahkan perlu disadari bahwa kearifan lokal mampu menjaga kelestarian dalam bentuk suatu panutan ataupun kebiasaan yang disakralkan dan dalam bentuk penanda yang harus dipatuhi oleh masyarakat yang sifatnya turun temurun. Kearifan lokal dalam pemanfaatan lahan kering di desa Bumi Pajo merupakan warisan budaya dari nenek moyang yang di wujudkan dalam beberapa kategori /bentuk yaitu:

1. "Toho ra dore"

Istilah ini merupakan wujud kepercayaan masyarakat terhadap arwah leluhur, masyarakat pada saat tertentu mempunyai tujuan/keinginan yaitu ketika mereka mengalami gagal panen atau terkena musibah, maka salah satu cara yang dilakukan oleh mereka adalah melakukan "toho $r$ a dore", bagi mereka "toho ra dore" adalah wujud permintaan maaf mereka terhadap arwah nenek moyang, supaya kegagalan panen yang menurut mereka itu berawal dari kemurkaan nenek moyang bisa berakhir.

2. "Berdo'a/Yasinan"

Bentuk kearifan lokal masyarakat dalam pemanfaatan lahan kering. untuk meminta perlindiungan kepada Allh SWT. Agar dijauhkan dari segala musibah serta usaha pertanian selamat dan hasil panen tercukupi sesuai dengan yang diharapkan.

3. "Wi'i Kamaya"

Dengan menyimpan dan membakar kemaya ini sebagai pertanda bahwa tanaman akan segera dipanen, jadi dengan cara ini secara tidak langsung memberitahukan pada mahluk yang ada di sekitar tanaman tersebut bahwa tanaman akan segera dipanen.

4. "Karaso dana/membersihkan lahan"

Kebiasaan masyarakat desa Bumi Pajo sebelum tanah/lahan di olah mereka membersihkannya dulu dari sisa-sisa tanaman, selesai mereka membersihkan lahan/tanah tersebut mereka tunggu sampai kering kalau sudah kering terus di bakar, tujuannya dengan membersihkan sisa tanaman tersebut maka hama tanaman yang bersembunyi di sekitar lokasi tersebut bisa terusir selain itu masyarakat di desa tersebut paham dengan membakar sisa tanaman dapat menambah bahan organik tanah sehigga menambah tingkat kesuburan tanah. 


\section{Peran Kearifan Lokal Masyarakat dalam Pemanfaatan Lahan Kering di desa Bumi Pajo Kecamatan Donggo Kabupaten Bima}

Kearifan lokal dalam pemanfaatan lahan kering bagi masyarakat desa Bumi Pajo kecamatan Donggo Kabupaten Bima berperan mengarahkan masyarakat untuk bekerja dengan baik dan benar atau dengan kata lain mengarahkan masyarakat cara bertani yang arif dan bijaksana, teutama dalam hal pengelolaan/pemanfaatan lahan kering sehingga terjaga keseimbangan dan kelestarian lingkungan. Beberapa peran kearifan lokal ini yaitu;

1. "Toho ra dore"

Kearifan lokal ini merupakan tradisi nenek moyang yang diwariskan pada generasi selanjutnya kemudian dijadikan budaya lokal oleh masyarakat setempat dan keberadaan budaya tersebut dirasakan manfaatnya sepertin hasil pertanian sesuai dengan yang diharapkannya begitu juga dengan cepat berakhirnya musibah atau bencana yang dialami masyarakat setempat.

2. Berdo'a/ Yasinan"

Perannya mengingatkan masyarakat desa Bumi Pajo kepada yang Maha Pencipta, pelindung dan pemberi rejeki, sehingga dalam memohon perlindungan/ keselamatan maupun rejeki mereka tidak lupa kepada yang maha penciptanya.

3. "Wi'i Kamaya/membakar kamaya"

Bagi masyarakat desa Bumi Pajo cara ini dilakukan sehari sebelum tanaman dipanen dan peran dari menyimpan/membakar kemaya ini yaitu memberitahukan/ mengingatkan pada mahluk yang ada disekitar itu bahwa tanaman tersebut akan di panen, sehingga pada saat dilakukan pemanenan mahlukmahluk tersebut tidak mengganggu.

4. "Karaso Danal membersihkan lahan dari sisa-sisa tanaman.

Membersihkan lahan dari sisa-sisa tanaman kemudian dibakar selalu dilakukan oleh mayarakat sebelum mereka malakukan pemanenan sangat berperan sebagai konservasi tanah/lahan' dalam menambah tingkat kesuburan tanah karena sisa tanaman yang dibakar tersebut pada akhirnya dapat berfungsi sebagai bahan organik tanah, selain itu dengan cara tersebut sekaligus bisa mengusir hama-hama pengganggu tanaman yang ada di wilayat sekitar itu.

\section{PENUTUP}

\section{A. Kesimpulan}

Kearifan lokal masyarakat desa Bumi Pajo Kecamatan Donggo Kabupaten Bima dikategorikan dalam beberapa bentuk yaitu; "Toho ra dore, Berdo'a/yasinan, Wi'i kamaya/membakar kamaya dan Karaso dana/membersihkan lahan", merupakan produk budaya masa lalu yang diwariskan nenek moyang yang patut secara terus-menerus dilestarikan bahkan diharapkan kedepannya dapat dikembangkan oleh anak cucu mereka karena kearifan lokal ini mempunyai peranan penting dalam dinamika lingkungan terutama dalam menjaga keseimbangan lingkungan. Kearifan lokal dalam pemanfaatan lahan kering bagi masyarakat desa Bumi Pajo berperan Mengarahkan masyarakat untuk bekerja dengan baik dan benar atau dengan kata lain mengarahkan masyarakat cara bertani yang arif dan bijaksana, teutama dalam hal pengelolaan/pemanfaatan lahan kering sehingga terjaga keseimbangan dan kelestarian lingkungan serta meningkatnya kesuburan tanah. Dengan demikian dalam hal bertani terutama bertani dilahan kering masyarakat bisa mendapatkan hasil sesuai dengan yang diinginkannya.

\section{B. Saran}

Berdasarkan kesimpulan diatas, maka dapat disarankan sebagai berikut:

1. Penelitian ini diharapkan dapat memberikan sumbangan ilmu pengetahuan bagi masyarakat Bima umumnya dan khususnya bagi masyarakat Desa Bumi Pajo Kecamatan Donggo Kabupaten Bima tentang bentuk dan peranan kearifan lokal dalam pemanfaatan lahan kering.

2. Hasil penelitian ini diharapkan memberikan informai kepada masyarakat Bima umumnya dan khususnya masyarakat desa Bumi Pajo tentang pentingnya melestarikan kearifan lokal sebagai wujud pelestarian budaya daerah terutama dalam pengelolaan sumberdaya lahan kering. 


\section{DAFTAR PUSTAKA}

An-Nabhani.

http://www.apapengertianahli.com/2014/0

9/pengertian-masyarakat- menurut-paraahli.html.

Arikunto, S., 2013. Prosedur Penelitian Suatu Pendekatan Praktik, PT Rineka Cipta, Jakarta.

Data BPS NTB (2002), http://www.academia.edu/4998142/ menunjukkan bahwa luas lahan kering.

Ernawi, 2010. Harmonisasi kearipan lokal dalam regulasi penataan ruang. www.penataanruang.net/taru/.../Sinkronis asiKearifanLokal 300410.pyogyakarta.

Guritno Bambang, 2011. Pola Tanam Di Lahan Kering. UB Press: Malang.

Hasan, 2007. Kamus Besar Bahasa Indonesia, Edisi Ketiga. Jakarta Balai Pustaka..

Nurmala, 2012. Pengatar Ilmu Pertanian. Graha ilmu: Yogyakarta.

Nyamai, (2010) Pemulihan lingkungan dengan bentuk kearifan lokal. pangasuhbumi.com/.../pemulihanlingkungan-dengan-kearifan-loka.

Pramudya, (2014). http://sosialsosiologi.blogspot.com/2012/1 2/definisi-masyarakat.html.

Sugiyono, 2013. Metode Penelitian Kuantitatif, Kualitatif Dan R Dan D.

Suwardji, 2008. Pengelolaan Sumberdaya Lahan Kering. Fakulta Peratanian. Universitas Mataram. 